Article

\title{
Biomass and Volume Yield in Mature Hybrid Poplar Plantations on Temperate Abandoned Farmland
}

\section{Benoit Truax $^{1, *}$, Daniel Gagnon ${ }^{1,2}$, Julien Fortier ${ }^{1,3}$ and France Lambert ${ }^{1}$}

1 Fiducie de recherche sur la forêt des Cantons-de-l'Est/Eastern Townships Forest Research Trust, 1 rue Principale, Saint-Benoît-du-Lac, QC J0B 2M0, Canada;

E-Mails: daniel.gagnon@uregina.ca (D.G.); fortier.julien@courrier.uqam.ca (J.F.); france.lambert@frfce.qc.ca (F.L.)

2 Department of Biology, University of Regina, 3737 Wascana Parkway, Regina, SK S4S 0A2, Canada

3 Département des Sciences Biologiques, Université du Québec à Montréal, C.P. 8888 succ. Centre-Ville, Montréal, QC H3C 3P8, Canada

* Author to whom correspondence should be addressed; E-Mail: btruax@frfce.qc.ca; Tel.: +1-819-821-8377.

External Editor: Eric J. Jokela

Received: 16 October 2014; in revised form: 24 November 2014 / Accepted: 2 December 2014 / Published: 12 December 2014

\begin{abstract}
In this study, we developed clone-specific allometric relationships, with the objective of calculating volume and biomass production after 13 years in 8 poplar plantations, located across an environmental gradient, and composed of 5 unrelated hybrid poplar clones. Allometry was found to be very similar for clones MxB-915311, NxM-3729 and DNxM-915508, all having P. maximoviczii parentage. Clones DxN-3570 and TxD-3230 also had a similar allometry; for a given DBH they have a lower stem volume, stem biomass and branch biomass than $P$. maximoviczii hybrids. Strong Site $\times$ Clone interactions were observed for volume and woody biomass growth, with DxN and TxD hybrids only productive on low elevation fertile sites, whereas $P$. maximovizcii hybrids were also very productive on higher elevation sites with moderate to high soil fertility. At the site level (5 clones mean), yield reached 27.5 and $22.7 \mathrm{~m}^{3} / \mathrm{ha} / \mathrm{yr}$. on the two best sites (high fertility and low elevation), confirming the great potential of southern Québec (Canada) for poplar culture. The productivity gap between the most and least productive sites has widened from year 8 to year 13, highlighting the need for high quality abandoned
\end{abstract}


farmland site selection in terms of climate and soil fertility. Although clone selection could optimize yield across the studied environmental gradient, it cannot fully compensate for inadequate site selection.

Keywords: Populus; afforestation; agroforestry; southern Québec (Canada); allometry; biomass and volume equations; site fertility; environmental gradient

\section{Introduction}

Worldwide, fast-growing hybrid poplar plantations have been increasingly used to intensify wood or biomass production on small areas of the land base [1,2]. Additionally, in agricultural landscapes, afforested poplar plantations can provide forest microclimate and habitats for native plants and wildlife [3-5]. Poplar plantations with high growth rates were found to be more efficient forest succession catalysts than slow growing ones, with some understory forest attributes (canopy closure, litter biomass) being restored after only a decade [6]. In addition, the faster a poplar plantation grows, the faster it will provide ecosystem services, such as carbon and nutrient storage and hydrological regulation in agricultural landscapes [7,8]. Consequently, increasing our knowledge of poplar plantation growth will have profound implications for both wood and biomass production, but also for the provision of ecosystem services in farmland.

The growth of poplars species, especially hybrid poplars, has been found to be very sensitive to environmental conditions. The effect of site fertility, growing season length or elevation, water availability and fertilization on poplar growth have been well documented over the years [9-12]. In addition, genotype or clone selection is essential to optimize yields across environmental gradients, as revealed by the many Genotype $\times$ Site interactions occurring in poplar growth that are recorded in the literature $[11,13,14]$. This is because species from the genus Populus, including hybrid poplars, show wide variations in functional traits such as cold-hardiness, soil nitrogen-form preferences, drought tolerance, chemical defense against herbivores, etc. [15-18].

Many poplar yield studies have focused on relatively young plantations, which were intended for the production of biomass for energy in short rotation coppice systems or agroforestry systems with high crop densities [19-21]. Several studies have also shown that more widely spaced poplar plantations can yield great wood volumes on longer rotations for pulp wood, sawlog and veneer industries [22-26]. However, few of these longer-term studies have been done across environmental gradients, with plantations of identical age composed of the same set of clones, allowing little opportunity to detect regional-scale yield variations that can exist for older plantations. Longer-term studies are also needed to confirm that early assessment of clone performances reflects long-term trends [27]. In addition, do early assessments of site productivity reflect longer-term trends, and what productivity gains can be expected as plantations age?

Yield data obtained across environmental gradients are especially important in providing decision tools for farmers or land managers, such as site fertility maps and models used for yield projection at the regional scale [28,29]. For example, a model that aims at predicting poplar growth, optimal rotation length and soil carbon sequestration, has been recently developed over broad ecoregions of the United 
States [30]. Similarly, a model has been proposed to predict and map poplar yield at a finer regional scale in the North Central region of the United States [31].

Although generalized biomass equations have been recently updated for Salicaceae taxa [32], species or genotype-specific allometric relationships are generally needed to accurately measure stem wood volume and aboveground biomass in plantations [33]. This is because different poplar hybrids may have different biomass allocation patterns or architecture [34]. Important variation in allometry have also been shown for different Salix clones grown in short rotation coppices [35].

Estimating volume and biomass yield of plantations at a regional scale also requires allometric relationships that were developed within the studied region. Zabek and Prescott [36] have argued that the use of allometric relationships for trees growing in locations outside of the areas in which the relationships were developed, can result in poor biomass estimations in poplar plantations, and such use is not supported by regression theory. This is because allometric tree growth relationships are influenced by the environmental conditions occurring in the specific areas in which they were developed. Inappropriate use of allometric relationships could also cause large errors in aboveground biomass carbon pool quantification [37]. In addition, age-specific relationships may be needed for certain species because tree allometry tends to change with stand age [38], a trend that was equally observed in short-rotation plantations [35].

In this study, we developed clone-specific allometric relationships, with the objective of calculating volume and biomass production after 13 years in 8 poplar plantations, located across an environmental gradient, and composed of 5 unrelated hybrid poplar clones. We also compared these volume and biomass yields with data obtained in the same experimental design after only 8 years [11], in order to determine the gain in productivity that has occurred in these poplar plantations from year 8 to year 13 . In addition, general allometric relationships were developed with the objective of comparing yield results calculated with clone-specific and general equations in 13 year-old plantations. The management implications of allometry and yield results are discussed.

\section{Materials and Methods}

\subsection{Study Sites, Experimental Design and Soil Characteristics}

The eight study sites are all located on privately owned abandoned farmland in the Eastern Townships region of southern Québec, Canada. These plantation sites were chosen along a regional gradient of elevation (climate) and soil characteristics (Table 1). Although some sites are located in hilly landscapes, all plantation sites were nearly flat, with slopes always under $5 \%$. All plantations were established on thick glacio-fluvial or glacial surface deposits ( $>2 \mathrm{~m}$ of available rooting depth), which is typical of agricultural sites of the studied region [39-41]. See Truax et al. [11] for a complete description of site characteristics.

A randomized block plantation design was used at each of the 8 sites, with 3 blocks (replicates) and 9 poplar clones. Only the 5 clones with the most different parentages were used in this study. Therefore, the present study was done with a total of 120 experimental plots $(8$ sites $\times 5$ clones $\times$ 3 blocks) analyzed in a factorial experiment [42]. In this study, blocking was used to control for environmental heterogeneity at the site level [43]. Blocks were nested within sites. Each block 
contained 5 experimental plots (one per clone). Each experimental plot was $12 \mathrm{~m} \times 12 \mathrm{~m}$ in size $\left(144 \mathrm{~m}^{2}\right)$ and contained 12 trees of a single clone, for a total of 180 trees per site and 1440 trees across the whole experimental design. At each site, one guard row of poplar trees was planted around the entire perimeter of the plantation to reduce edge effects on poplar growth.

Table 1. Elevation (Elev.) and soil characteristics $(0-15 \mathrm{~cm})$ of the hybrid poplar plantation sites [11].

\begin{tabular}{|c|c|c|c|c|c|c|c|c|c|c|}
\hline Sites & $\begin{array}{c}\text { Elev. } \\
\text { (m) }\end{array}$ & $\begin{array}{c}\text { Textural } \\
\text { Class } \\
\end{array}$ & $\begin{array}{c}\text { pH } \\
\text { (Water) }\end{array}$ & $\begin{array}{c}\mathrm{C} / \mathrm{N} \\
\text { Ratio }\end{array}$ & $\begin{array}{c}\text { Organic } \\
\text { Matter (\%) }\end{array}$ & $\begin{array}{c}\text { N total } \\
(\mathrm{g} / \mathrm{kg})\end{array}$ & $\begin{array}{c}P \\
(\mathrm{~kg} / \mathrm{ha}) \\
\end{array}$ & $\begin{array}{c}\mathrm{Ca} \\
(\mathrm{kg} / \mathrm{ha}) \\
\end{array}$ & $\begin{array}{c}\mathrm{K} \\
(\mathrm{kg} / \mathrm{ha}) \\
\end{array}$ & $\begin{array}{c}\text { Mg } \\
\text { (kg/ha) }\end{array}$ \\
\hline Bedford & 80 & Sandy loam & 5.36 & 8.2 & 4.87 & 3.20 & 76.6 & 2781 & 156 & 183 \\
\hline Brompton & 170 & Clay loam & 5.51 & 8.9 & 5.81 & 2.91 & 60.0 & 2745 & 217 & 271 \\
\hline Ste-Catherine & 230 & Loam & 5.00 & 11.3 & 6.69 & 3.13 & 50.4 & 594 & 117 & 171 \\
\hline Fitch Bay & 260 & Loam & 5.30 & 10.1 & 6.14 & 3.03 & 11.9 & 1297 & 109 & 226 \\
\hline Ham & 320 & Loam & 4.77 & 10.5 & 8.46 & 3.97 & 25.5 & 616 & 93 & 51 \\
\hline Melbourne & 330 & Loam & 5.37 & 10.4 & 6.67 & 3.36 & 17.4 & 1403 & 107 & 104 \\
\hline La Patrie & 440 & Silty loam & 5.09 & 9.4 & 6.34 & 3.51 & 58.3 & 2079 & 125 & 103 \\
\hline Stornoway & 450 & Silty loam & 5.45 & 11.8 & 9.85 & 4.34 & 9.0 & 3100 & 136 & 209 \\
\hline SE & - & - & 0.04 & 0.1 & 0.25 & 0.14 & 7.8 & 129 & 8 & 13 \\
\hline$p$ & - & - & $<0.001$ & $<0.001$ & $<0.001$ & $<0.001$ & $<0.001$ & $<0.001$ & $<0.001$ & $<0.001$ \\
\hline
\end{tabular}

This design allowed us to test 5 poplar clones in 8 different sites simultaneously, as a series of similar experiments, a procedure quite common in crop cultivar evaluation [44]. All poplars were planted with a spacing of $4 \mathrm{~m} \times 3 \mathrm{~m}$, for an initial density of 833 stems per hectare.

Site preparation included ploughing and disking each abandoned farmland site in fall 1999, to physically enhance soil conditions and facilitate plantation the following spring. Neither lime nor fertilizer applications (organic or chemical) were made before or during the course of the study. In the spring of 2000, bare-root stocks with 2 m-long stems were planted manually with shovels at 30 to $40 \mathrm{~cm}$ depth, in 3 rows of 4 trees per experimental plot, $4 \mathrm{~m}$ between rows and $3 \mathrm{~m}$ between trees within a row. Planting stock (1-0) was provided by the Berthierville nursery of the Ministère des Ressources naturelles et de la Faune (MRNF) of Québec.

Five unrelated hybrid poplar clones were used in this study: P. trichocarpa $\times$ deltoides (TxD-3230), P. deltoides $\times$ nigra $(\mathrm{DxN}-3570)$, P. canadensis $\times$ maximowiczii $(\mathrm{DNxM}-915508)$, P. nigra $\times$ maximowiczii (NxM-3729) and P. maximowiczii $\times$ balsamifera (MxB-915311). These clones had been selected for superior disease resistance/tolerance and growth characteristics in MRNF genetic selection trials in southern Quebec [45].

None of the planted poplar clones were protected against deer browsing with fences or chemical deterrents. Competing vegetation was eliminated with glyphosate herbicide application over the entire plantation area in June 2000, and between plantation rows only in June 2001. In 2007, one tree per plot was harvested at the end of the 8th growing season to develop allometric relationships and evaluate plantation yields [11].

For soil characterization, one composite soil sample was taken at $0-15 \mathrm{~cm}$ depth (mainly the Ap horizon) in each experimental plot in 2007, in order to determine soil $\mathrm{pH}$ and concentrations of $\mathrm{Ca}$, $\mathrm{Mg}, \mathrm{K}$, available $\mathrm{P}$, total $\mathrm{N}$, total $\mathrm{C}$ and $\mathrm{C} / \mathrm{N}$ ratio (Table 1). A composite sample at the block level was 
used to determine soil textural class (Table 1). Detailed methods for soil sample analyses are provided in a previous study [11].

\subsection{Destructive Sampling}

As in our previous yield studies [11,21,34], we used a model-based sampling approach [46], by developing new allometric relationships for each hybrid poplar clone to assess yields. The choice of this sampling approach was motivated by the fact that hypothesis testing (Clone and Site effects, and Site $\times$ Clone interactions) in short-rotation forestry often requires that object-specific allometric relationship have to be developed and destructive sampling cannot be avoided [35].

At the end of the 13th growing season (late October 2012), we selected one representative hybrid poplar in each experimental plot, for a total 120 trees (each tree represents $12 \mathrm{~m}^{2}$ of plot area). In each plot, this representative tree was selected because it was the closest to the average diameter at breast height of all hybrid poplars in the plot. The diameter range at breast height (DBH) for these 120 trees was $4.3-37.3 \mathrm{~cm}$. After leaf fall, trees were cut just above the root collar and aboveground compartments (branches and stem) were separated and weighed fresh using a tripod scale. Sub-samples from the stem sections described below and from branches were immediately weighed in the field and taken back to the lab for determining dry weight.

In order to calculate stem volume (outside of the bark) for the 120 sampled trees the following measurements were taken for different DBH classes. For very large trees (DBH $>30 \mathrm{~cm})$, stem volume was calculated for five sections of the stem: (1) tree base diameter to DBH; (2) $\mathrm{DBH}$ to $30 \mathrm{~cm}$ diameter; (3) 30 to $20 \mathrm{~cm}$ diameter; (4) 20 to $10 \mathrm{~cm}$ diameter; and (5) 10 to $3 \mathrm{~cm}$ diameter. For large trees $(\mathrm{DBH}>20 \mathrm{~cm})$, stem volume was calculated for four sections of the stem: (1) tree base diameter to $\mathrm{DBH}$; (2) $\mathrm{DBH}$ to $20 \mathrm{~cm}$ diameter; (3) 20 to $10 \mathrm{~cm}$ diameter; and (4) $10 \mathrm{~cm}$ diameter to $3 \mathrm{~cm}$ diameter. For medium size trees $(\mathrm{DBH}=10-20 \mathrm{~cm})$, stem volume was calculated for three sections of the stem: (1) tree base diameter to $\mathrm{DBH}$; (2) $\mathrm{DBH}$ to $10 \mathrm{~cm}$ diameter; and (3) $10 \mathrm{~cm}$ diameter to $3 \mathrm{~cm}$ diameter. For smaller trees $(\mathrm{DBH} \leq 10 \mathrm{~cm})$ volume was calculated for two sections of the stem: (1) tree base diameter to $\mathrm{DBH}$; and (2) $\mathrm{DBH}$ to $3 \mathrm{~cm}$ diameter. Volumes of different stem sections were then summed to obtain total stem volume for each of the sampled hybrid poplars. Volume calculations of each stem section were made using the following equation [47]:

$$
V=\pi / 12\left(D_{1}{ }^{2}+D_{2}{ }^{2}+D_{1} D_{2}\right) L
$$

where, $V$ is the volume of a stem section, $D_{1}$ is the base diameter of the stem section, $D_{2}$ is the diameter at the top of the stem section, and $L$ is the length of the stem section.

\subsection{Regression Procedures for Allometric Relationships}

With stem volume and stem and branch biomass data of 24 trees per clone, regression models for stem volume and biomass compartments vs. DBH were developed, with DBH being the predictor variable $(x)$ and biomass (stem or branches) and stem volume being the response variable $(Y)$ (Table 2). Residuals of the different models were plotted and compared to a normal distribution in order to determine the goodness-of-fit according to the Shapiro-Wilk $W$ test. Regression model selection was based on (1) model parameters significance; (2) the fit $\left(R^{2}\right)$ of the regression and (3) the 
goodness of fit $(W)$ or normality in residuals distribution. Therefore, when the fit of two different models with significant parameters was comparable for a given clone, the model with the highest normality in the distribution of residuals was always chosen.

Table 2. Clone specific allometric relationships between diameter at breast height $(\mathrm{cm})$, as the predictor variable $(x)$, and stem volume $\left(\mathrm{dm}^{3}\right)$, stem dry biomass $(\mathrm{kg})$, branch dry biomass $(\mathrm{kg})$, and woody aboveground dry biomass as the response variables $(Y)$. For each model, goodness of fit expressed by the Shapiro-Wilk statistic $(W)$ is presented with its associated $p$-value.

\begin{tabular}{|c|c|c|c|c|c|c|c|}
\hline $\begin{array}{c}\text { Tree } \\
\text { Compartments } \\
\text { and Clones }\end{array}$ & $\begin{array}{c}\text { Trees } \\
\text { Harvested }(n)\end{array}$ & $\begin{array}{c}\text { DBH } \\
\text { Range (cm) }\end{array}$ & Model & $R^{2}$ & $F$-Value & $W$ & $p<W$ \\
\hline \multicolumn{8}{|l|}{ Stem volume } \\
\hline MxB-915311 & 24 & $10.2-27.4$ & $Y=0.0939 x^{2.6096}$ & 0.98 & 963 & 0.97 & 0.65 \\
\hline DNxM-915508 & 24 & $10.8-36.1$ & $Y=0.0733 x^{2.6769}$ & 0.99 & 2011 & 0.94 & 0.18 \\
\hline TxD-3230 & 24 & $10.8-35.7$ & $Y=0.0651 x^{2.6589}$ & 0.98 & 1146 & 0.95 & 0.36 \\
\hline DxN-3570 & 24 & $4.3-37.3$ & $Y=0.1235 x^{2.4825}$ & 0.99 & 3064 & 0.87 & 0.01 \\
\hline NxM-3729 & 24 & $11.4-30.2$ & $Y=0.0589 x^{2.7366}$ & 0.98 & 1261 & 0.98 & 0.96 \\
\hline \multicolumn{8}{|l|}{ Stem biomass } \\
\hline MxB-915311 & 24 & $10.2-27.4$ & $Y=0.0426 x^{2.517}$ & 0.98 & 944 & 0.97 & 0.72 \\
\hline DNxM-915508 & 24 & $10.8-36.1$ & $Y=0.0392 x^{2.5438}$ & 0.99 & 1879 & 0.96 & 0.36 \\
\hline TxD-3230 & 24 & $10.8-35.7$ & $Y=0.0326 x^{2.5278}$ & 0.97 & 648 & 0.97 & 0.58 \\
\hline DxN-3570 & 24 & $4.3-37.3$ & $Y=0.0476 x^{2.4193}$ & 0.99 & 1786 & 0.95 & 0.26 \\
\hline NxM-3729 & 24 & $11.4-30.2$ & $Y=0.0397 x^{2.537}$ & 0.98 & 910 & 0.98 & 0.97 \\
\hline \multicolumn{8}{|l|}{ Branch biomass } \\
\hline MxB-915311 & 24 & $10.2-27.4$ & $Y=2.9548 e^{0.1056 x}$ & 0.82 & 99 & 0.93 & 0.10 \\
\hline DNxM-915508 & 24 & $10.8-36.1$ & $Y=0.0194 x^{2.4201}$ & 0.93 & 303 & 0.97 & 0.70 \\
\hline TxD-3230 & 24 & $10.8-35.7$ & $Y=0.0837 x^{1.7453}$ & 0.91 & 207 & 0.94 & 0.21 \\
\hline DxN-3570 & 24 & $4.3-37.3$ & $\begin{array}{c}Y=0.0513 x^{2}-0.6495 x \\
+4.3473\end{array}$ & 0.99 & 1026 & 0.98 & 0.91 \\
\hline NxM-3729 & 24 & $11.4-30.2$ & $Y=2.975 e^{0.1049 x}$ & 0.95 & 405 & 0.96 & 0.36 \\
\hline \multicolumn{8}{|l|}{ Abovegr. biomass } \\
\hline MxB-915311 & 24 & $10.2-27.4$ & $Y=0.0937 x^{2.3499}$ & 0.99 & 1678 & 0.94 & 0.21 \\
\hline DNxM-915508 & 24 & $10.8-36.1$ & $Y=0.0588 x^{2.5077}$ & 0.99 & 2020 & 0.96 & 0.42 \\
\hline TxD-3230 & 24 & $10.8-35.7$ & $Y=0.0678 x^{2.3597}$ & 0.97 & 683 & 0.95 & 0.28 \\
\hline DxN-3570 & 24 & $4.3-37.3$ & $Y=0.078 x^{2.3119}$ & 0.996 & 5017 & 0.97 & 0.65 \\
\hline NxM-3729 & 24 & $11.4-30.2$ & $Y=0.0769 x^{2.4121}$ & 0.98 & 932 & 0.98 & 0.88 \\
\hline
\end{tabular}

Selected regression models were almost all in the form of a power function, but the relationship for clone DxN-3570 between DBH and branch biomass was best described by a polynomial function, and by an exponential function for clones MxB-915311 and NxM-3729 (Table 2). All models developed with data obtained after 13 years were highly significant $(p<0.001)$ and all model parameters were also highly significant $(p<0.001)$, with the exception of the intercept parameter for the relationship between DBH and branch biomass for clone DxN-3570 $(p<0.01)$ (Table 2). 
We also developed clone-specific allometric relationships between DBH and woody aboveground biomass (stem + branches) because these models are very useful to researchers who develop general biomass equations for different tree taxa [32]. These models were not used to calculate the biomass yields presented in this study, but they produced very similar aboveground woody biomass results compared to the method we chose (calculating stem and branch biomass separately, and then summing the two compartments). At the site level, aboveground woody biomass estimates obtained with the two methods showed a maximum variation of $1.4 \%$.

In addition, we produced general regression models, including all 5 clones, which were done with the 120 harvested 13 year-old trees (Table 3). We have also developed general models for stem volume and biomass using the 120 trees harvested in 2007 in 8 year-old plantations and the 120 trees harvested in 2012 in 13 year-old plantations. All these models are in the form of power functions, with all models and model parameters being significant at $p<0.001$. Although the Shapiro-Wilk test is the best omnibus test of normality, it is inappropriate for testing residual normality for larger sample sizes $(n>50)$ [48]. As proposed by Chambers et al. [49], we used normal quantile-quantile plots (Q-Q plots) as a diagnostic tool for verifying normality of residual distribution for the general regression models provided in Table 3.

Table 3. General ( 5 clones) allometric relationships between diameter at breast height $(\mathrm{cm})$, as the predictor variable $(x)$, and stem volume $\left(\mathrm{dm}^{3}\right)$, stem dry biomass $(\mathrm{kg})$, branch dry biomass $(\mathrm{kg})$, and woody aboveground dry biomass as the response variables $(Y)$. Allometric relationships for 8 year-old poplars are from Truax et al. [11].

\begin{tabular}{ccccccc}
\hline Tree Compartments & Age (Years) & $\begin{array}{c}\text { Trees } \\
\text { Harvested (n) }\end{array}$ & $\begin{array}{c}\text { DBH } \\
\text { Range (cm) }\end{array}$ & Model & $\boldsymbol{R}^{\mathbf{2}}$ & $\boldsymbol{F}$-Value \\
\hline \multirow{3}{*}{ Stem volume } & 8 & 120 & $3-25.2$ & $Y=0.102 x^{2.5334}$ & 0.99 & 12,487 \\
& 13 & 120 & $4.3-37.3$ & $Y=0.1014 x^{2.5562}$ & 0.98 & 6424 \\
& $8 \& 13$ & 240 & $3-37.3$ & $Y=0.0945 x^{2.5725}$ & 0.99 & 23,089 \\
\hline \multirow{2}{*}{ Stem biomass } & 8 & 120 & $3-25.2$ & $Y=0.0741 x^{2.27}$ & 0.97 & 3740 \\
& 13 & 120 & $4.3-37.3$ & $Y=0.0427 x^{2.49}$ & 0.97 & 4257 \\
& $8 \& 13$ & 240 & $3-37.3$ & $Y=0.0562 x^{2.3893}$ & 0.98 & 9641 \\
\hline & 8 & 40 & $5.5-22.5$ & $Y=0.0947 x^{1.8164}$ & 0.90 & 338 \\
Branch biomass & 13 & 120 & $4.3-37.3$ & $Y=0.0314 x^{2.1659}$ & 0.81 & 504 \\
Aboveground biomass & 13 & 120 & $4.3-37.3$ & $Y=0.071 x^{2.4055}$ & 0.96 & 3108 \\
\hline
\end{tabular}

\subsection{Volume and Biomass Calculations}

In order to evaluate volume and biomass production in 13 year-old plantations, we recorded DBH values of each living tree in the experimental design using a caliper (mean of two diameter measurements taken perpendicularly). DBH measurements were taken from late October to early November 2012, at the end of the 13th growing season. For each living tree, volume and biomass of different tree components were calculated by putting the DBH value in the selected clone-specific allometric relationships. Then, total plot volume and biomass was calculated by summing volume and biomass of individual living trees in the plot. Mean volume and biomass per tree data were obtained by dividing total plot volume and biomass by the number of living trees in the plot. Total biomass and 
volume yield data per plot were then scaled up to one hectare and divided by poplar age (13 years) in order to produce mean annual yield data for purposes of comparison with other studies. The same procedure was repeated using the general allometric relationships in order to have volume and biomass data calculated with both clone-specific and general allometric relationships for comparison purposes in 13 year-old poplar plantations.

In this study, the term "woody biomass" represents the sum of stems and branches biomass on a per hectare basis, which is the total harvestable dry aboveground woody biomass. The term "volume" refers to the stem wood volume outside the bark.

\subsection{Statistical Analyses}

ANOVA tables were constructed in accordance with Petersen (1985), where degrees of freedom, sum of squares, mean squares and $F$ values were computed. When a factor is declared statistically significant (Sites, Clones and Sites $\times$ Clones interactions), the standard error of the mean (SE) was used to evaluate differences between means for three levels of significance ${ }^{*} p<0.05, * * p<0.01$ and $* * * p<0.001)$. All of the ANOVAs were run with the complete set of data ( 8 sites, 5 clones, 3 blocks $=120$ experimental plots).

To test the statistical significance of clone (genotype) and tree age effects on hybrid poplar growth parameters, we performed a series of analyses of covariance (ANCOVA) using DBH as a continuous covariate, and genotype or plantation age, as nominal main effects. Data were $\log (\ln )$ transformed prior to these analyses by assuming that hybrid poplar allometry is described by a power function, although it was not always the best model according to selection criteria (Table 2). All statistical analyses were done using JMP 11 from SAS Institute (Cary, NC, USA).

\section{Results and Discussion}

\subsection{Influence of Genotype and Plantation Age on Poplar Allometry}

The allometric relationships developed between DBH and volume or biomass of the different tree compartments for 13 year-old hybrid poplars suggested an important influence of the genotype on allometry (Figure 1, Table 2). In addition, results from the analyses of covariance suggest a significant Genotype effect on the regression between $\mathrm{DBH}$ and volume or biomass of different tree compartments (Table 4). For most tree compartments studied, allometry was found to be very similar for P. maximoviczii hybrids (Figure 1). No significant Genotype effect was observed on stem, branch and aboveground biomass, when the three P. maximoviczii hybrids (clones MxB-915311, DNxM-915508 and NxM-3729) were used as different treatment levels in the analysis of covariance (Table 4). Likewise, allometry was also found to be relatively similar for clones DxN-3570 and TxD-3230, which are both Euramerican hybrids (Figure 1). No significant Genotype effect was observed on stem and aboveground woody biomass, when these two clones were used as different treatment levels in the analysis of covariance (Table 4). More generally, for all tree compartments studied, highly significant Genotype effects $(p<0.001)$ were also observed when the group formed by $P$. maximoviczii hybrids and the group formed by Euramerican hybrids were the treatment levels used in the analysis of covariance (Table 4). These trends may be related to the fact that for a given tree 
DBH, Euramerican hybrids tended to have lower stem volume, stem biomass, branch biomass and aboveground biomass than P. maximoviczii hybrids (Figure 1). This evidence suggests that accurate estimates of wood or biomass production and carbon storage in tree biomass for clones of different parentages will require the use of genotype-specific, or perhaps hybrid-specific allometric relationships. Similar conclusions have been drawn regarding biomass estimates in short-rotation coppices of willows [35]. The implications for yield results of using clone-specific vs. general allometric relationships will be further discussed in Section 3.3.

Figure 1. Clone-specific allometric relationships between diameter at breast height $(\mathrm{cm})$ and stem volume $\left(\mathrm{dm}^{3}\right)$, stem dry biomass $(\mathrm{kg})$, branch dry biomass $(\mathrm{kg})$, and woody aboveground dry biomass (kg). The blue line (clone MxB-915311) is sometimes overlapped by the green (clone NxM-3729) and orange (clone DNxM-915508) lines.
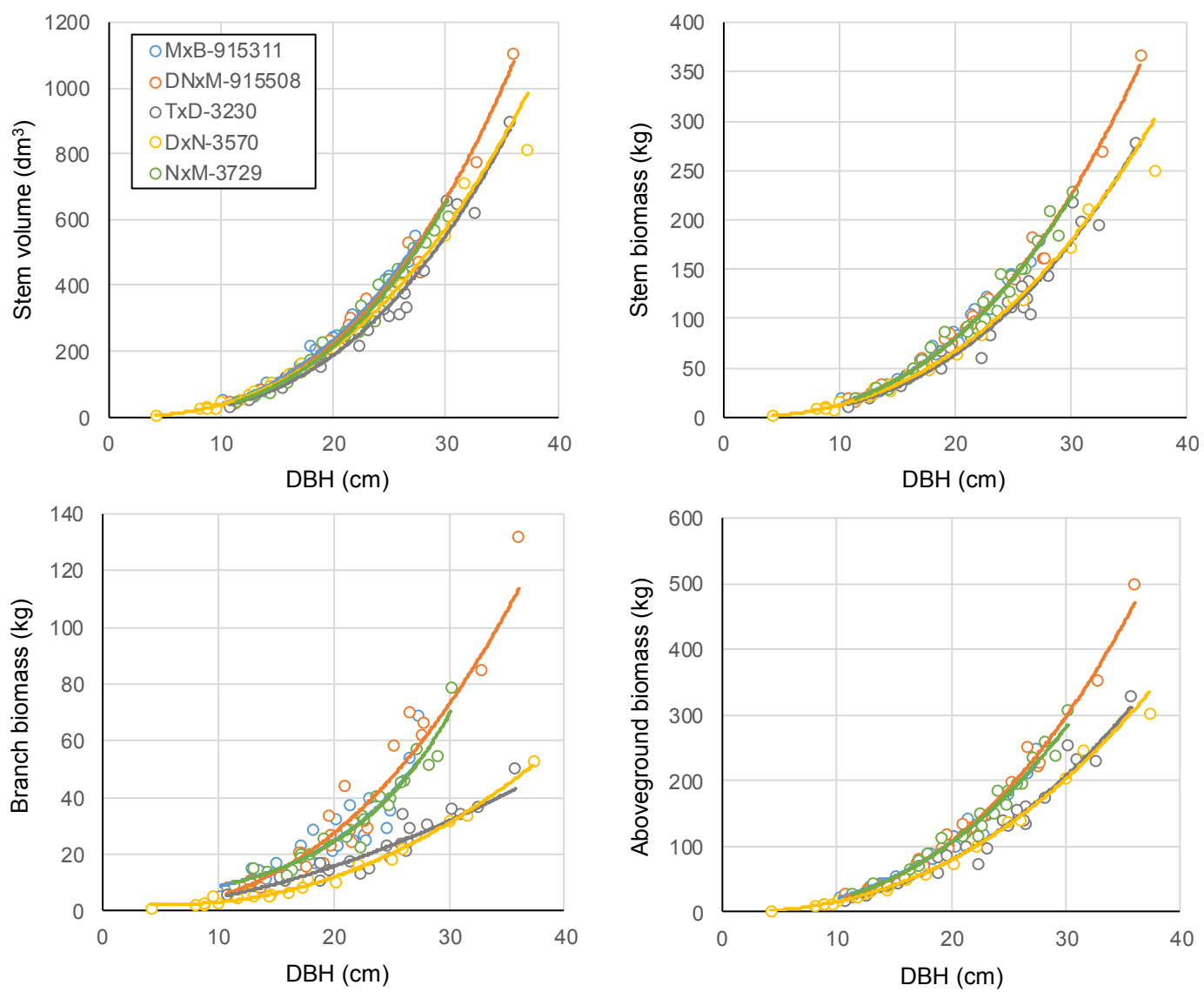

Our results also confirm previous observations done in poplar agroforestry systems of the studied region (southern Québec, Canada). In 9 year-old poplar buffer strips, allometric relationships between DBH and branch biomass were similar for clones MxB-915311 and DNxM-915508, while clone DxN-3570 had much lower branch biomass at a given DBH [34]. Yet, 7 year-old poplar clones of different parentages $(\mathrm{D}, \mathrm{DxB}$ and $\mathrm{DxN})$ showed little variation in allometry of woody biomass compartments [50]. Thus, additional studies involving destructive sampling are needed to evaluate the allometry of clones that have different genetic assemblages. Eventually, general allometric relationships for different groups of clones or hybrids could be developed because some clones and group of clones showed a very similar allometry (Figure 1, Table 4). 
Table 4. Significance level ( $p$-value) of the main effects for the analysis of covariance (ANCOVA) testing DBH, as a continuous covariate, and genotype or plantation age, as nominal main effects on the different growth variables (stem volume, stem biomass, branch biomass and aboveground woody biomass). The covariate was always significant at $p<0.001$. The Genotype effect was tested on 13 year-old poplar data, while the Plantation age effect was tested on the data set combining data from 8 and 13 year-old poplars. Data were log transformed prior to analysis; NS = non significant.

\begin{tabular}{ccccc}
\hline $\begin{array}{c}\text { Main Effects and } \\
\text { Treatment Levels }\end{array}$ & $\begin{array}{c}\text { Stem } \\
\text { Volume } \\
\left(\mathbf{d m}^{3} / \text { tree) }\right.\end{array}$ & $\begin{array}{c}\text { Stem } \\
\text { Biomass } \\
(\mathbf{k g} / \text { tree) }\end{array}$ & $\begin{array}{c}\text { Branch } \\
\text { Biomass } \\
\text { (kg/tree) }\end{array}$ & $\begin{array}{c}\text { Aboveground } \\
\text { Biomass (kg/tree) }\end{array}$ \\
$\begin{array}{c}\text { Genotype } \\
\text { MxB, NxM, DNxM, TxD and }\end{array}$ & $<0.001$ & $<0.001$ & $<0.001$ & $<0.001$ \\
DxN & $<0.05$ & $\mathrm{NS}$ & $\mathrm{NS}$ & $\mathrm{NS}$ \\
MxB, NxM and DNxM & $<0.01$ & $\mathrm{NS}$ & $<0.001$ & $\mathrm{NS}$ \\
TxD and DxN & $<0.001$ & $<0.001$ & $<0.001$ & $<0.001$ \\
Euramerican and & & & & \\
$\begin{array}{c}\text { P. maximoviczii hybrids } \\
\text { Plantation age }\end{array}$ & $<0.01$ & $<0.05$ & $<0.05$ & \\
8 and 13 years & & & & \\
\hline
\end{tabular}

General models developed with data from the 5 clones $(n=120)$ for stem volume and biomass suggest a significant Plantation age effect on poplar allometry, as revealed by the analysis of covariance (Figure 2, Tables 3 and 4). Although the size of the age effect seems more marginal for stem volume estimation, it was likely important for stem biomass, especially at larger DBH value. For example, a hybrid poplar with $30 \mathrm{~cm}$ of DBH would have an estimated stem volume of $563 \mathrm{dm}^{3}$ using the model developed with 8 year-old trees and of $605 \mathrm{dm}^{3}$ using the model developed with 13 year-old trees ( $7 \%$ difference between the two estimates). However, for the same tree, stem biomass estimates would be 167 and $203 \mathrm{~kg}$, if model developed with 8 and 13 year-old trees were used respectively ( $18 \%$ difference between the two estimates). This trend may be the consequence of the influence of tree age on stem wood density. As observed by DeBell et al. [51], wood density of three clones with a $P$. trichocarpa parentage showed a continuous increase from year 5 to year 9 . Therefore, using a biomass equation developed with juvenile poplars might result in an underestimation of the biomass of more mature poplars, and vice versa, because of these possible wood density changes over the years. 
Figure 2. General (5 clones combined) allometric relationships between diameter at breast height $(\mathrm{cm})$ and stem volume $\left(\mathrm{dm}^{3}\right)$, and stem dry biomass $(\mathrm{kg})$ in poplar plantations. The black line indicates the general model developed combining the 8 and 13 year data obtained from trees harvested in the poplar plantations.
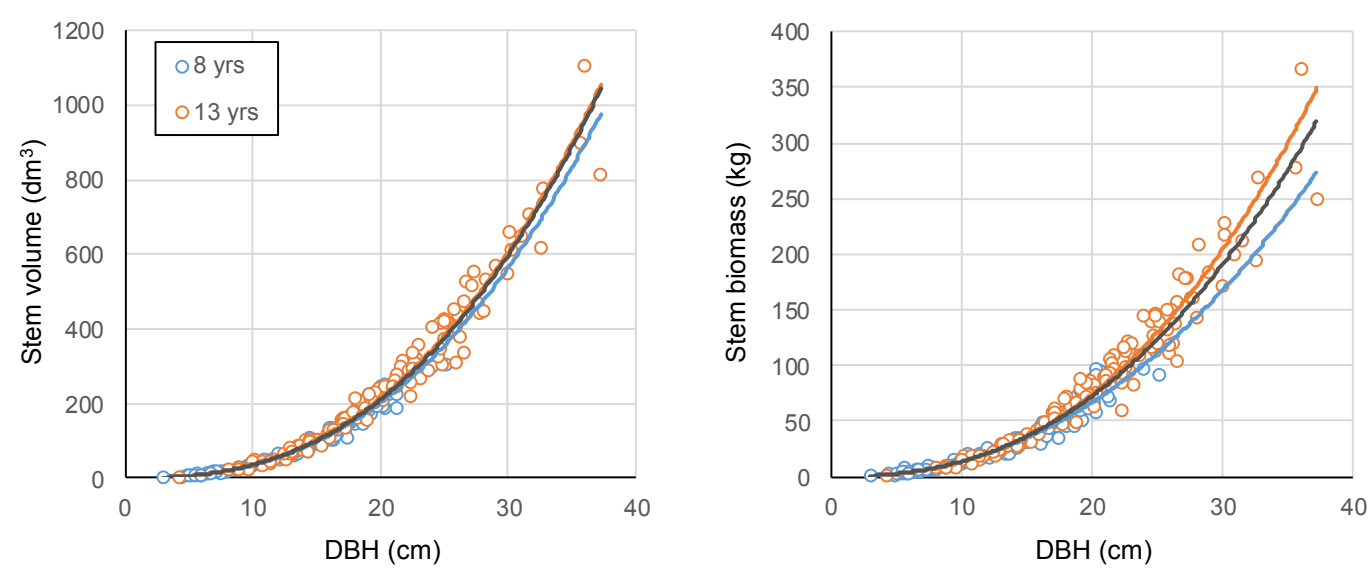

\subsection{Hybrid Poplar Yields in Mature Plantations}

After 13 years, strong Site $\times$ Clone interactions were observed this study, suggesting that the 5 poplar genotypes had a different growth response to the plantation environment across the studied ecological gradient (Tables 1, 5 and 6). At the site level, very high yields can be achieved in poplar plantations in southern Québec, but moderate to high site fertility is imperative for achieving high productivity (Table 6). In the same experimental design, Truax et al. [11] showed that soil $\mathrm{P}$ availability and elevation were strongly correlated with 8 year-old poplar productivity. Five years later, sites having the highest soil P availability and lower elevation (Bedford, Brompton and Ste-Catherine) were still the most productive. High yields were also observed at high elevation, at the fertile site of La Patrie (440 m), especially for P. maximoviczii hybrids (Table 6), a trend that also emerged in our previous study.

Located at $80 \mathrm{~m}$ of elevation in the St. Lawrence Valley and having the highest soil $\mathrm{P}$ availability, the Bedford site was the most productive. The Bedford site was also recently abandoned and is the only site that is surrounded by intensive row crop agriculture, which is an indication of the high soil quality at this location. Depending on the clone used at this site, mean DBH reached $23.3-30.4 \mathrm{~cm}$, while mean tree volume and mean annual yield reached $360-637 \mathrm{dm}^{3} /$ tree and $20.5-31.4 \mathrm{~m}^{3} / \mathrm{ha} /$ year or 9.0-14.3 t/ha/year (Tables 5 and 6). In the province of Québec (Canada), these are the highest yields ever reported in the literature for poplar plantations with a relatively low stem density at planting (833 tree/ha) [52]. Only narrow riparian buffers bordering fertile agricultural sites and short-rotation coppice systems, at much higher tree densities, were found to be more productive than the Bedford site in southern Québec [34,53]. 
Table 5. Site $\times$ Clone interaction for mean tree $\mathrm{DBH}$, stem volume per tree, stem biomass per tree, branch biomass per tree, and aboveground woody biomass per tree in 13 year-old poplar plantations.

\begin{tabular}{|c|c|c|c|c|c|c|}
\hline Sites & Clones & $\begin{array}{l}\text { DBH } \\
(\mathrm{cm})\end{array}$ & $\begin{array}{c}\text { Stem Volume } \\
\left(\mathrm{dm}^{3} / \text { tree }\right)\end{array}$ & $\begin{array}{c}\text { Stem Biomass } \\
(\mathrm{kg} / \text { tree })\end{array}$ & $\begin{array}{c}\text { Branch Biomass } \\
(\mathrm{kg} / \text { tree })\end{array}$ & $\begin{array}{c}\text { Woody Biomass } \\
(\mathrm{kg} / \text { tree })\end{array}$ \\
\hline \multirow{5}{*}{ Bedford } & MxB-915311 & 23.3 & 360 & 122 & 36.3 & 158 \\
\hline & DNxM-915508 & 27.8 & 553 & 189 & 61.9 & 251 \\
\hline & TxD-3230 & 28.9 & 531 & 170 & 30.2 & 200 \\
\hline & DxN-3570 & 30.4 & 637 & 197 & 33.9 & 231 \\
\hline & NxM-3729 & 28.0 & 549 & 190 & 58.4 & 248 \\
\hline \multirow{5}{*}{ Brompton } & MxB-915311 & 22.8 & 347 & 117 & 35.5 & 153 \\
\hline & DNxM-915508 & 23.8 & 374 & 130 & 43.3 & 174 \\
\hline & TxD-3230 & 27.7 & 467 & 150 & 27.9 & 178 \\
\hline & DxN-3570 & 23.9 & 342 & 108 & 18.9 & 126 \\
\hline & NxM-3729 & 26.0 & 451 & 158 & 47.3 & 205 \\
\hline \multirow{5}{*}{ Ste-Catherine } & MxB-915311 & 18.6 & 204 & 70 & 22.1 & 92 \\
\hline & DNxM-915508 & 21.1 & 272 & 96 & 32.4 & 129 \\
\hline & TxD-3230 & 22.2 & 280 & 92 & 19.5 & 111 \\
\hline & DxN-3570 & 16.2 & 156 & 50 & 9.1 & 59 \\
\hline & NxM-3729 & 21.8 & 290 & 105 & 31.7 & 136 \\
\hline \multirow{5}{*}{ La Patrie } & MxB-915311 & 22.0 & 312 & 106 & 31.8 & 138 \\
\hline & DNxM-915508 & 20.6 & 251 & 89 & 30.3 & 120 \\
\hline & TxD-3230 & 26.7 & 443 & 143 & 26.6 & 169 \\
\hline & DxN-3570 & 13.7 & 97 & 31 & 6.1 & 37 \\
\hline & NxM-3729 & 24.4 & 380 & 135 & 40.0 & 175 \\
\hline \multirow{5}{*}{ Melbourne } & MxB-915311 & 21.9 & 321 & 109 & 32.9 & 142 \\
\hline & DNxM-915508 & 21.5 & 281 & 99 & 33.5 & 133 \\
\hline & TxD-3230 & 23.4 & 299 & 98 & 20.9 & 119 \\
\hline & DxN-3570 & 15.8 & 130 & 42 & 7.7 & 50 \\
\hline & NxM-3729 & 21.4 & 263 & 96 & 28.7 & 125 \\
\hline \multirow{5}{*}{ Fitch Bay } & MxB-915311 & 18.7 & 212 & 73 & 23.1 & 96 \\
\hline & DNxM-915508 & 17.9 & 229 & 81 & 27.1 & 108 \\
\hline & TxD-3230 & 25.0 & 365 & 119 & 23.6 & 142 \\
\hline & DxN-3570 & 9.0 & 29 & 10 & 2.7 & 13 \\
\hline & NxM-3729 & 20.9 & 263 & 95 & 29.1 & 124 \\
\hline \multirow{5}{*}{ Ham } & MxB-915311 & 15.4 & 129 & 45 & 15.9 & 61 \\
\hline & DNxM-915508 & 15.4 & 120 & 44 & 15.4 & 59 \\
\hline & TxD-3230 & 17.4 & 146 & 50 & 12.7 & 62 \\
\hline & DxN-3570 & 9.4 & 39 & 13 & 3.3 & 16 \\
\hline & NxM-3729 & 15.5 & 113 & 44 & 15.6 & 59 \\
\hline \multirow{5}{*}{ Stornoway } & MxB-915311 & 13.3 & 83 & 30 & 12.2 & 42 \\
\hline & DNxM-915508 & 10.8 & 51 & 20 & 7.1 & 27 \\
\hline & TxD-3230 & 11.6 & 50 & 18 & 6.3 & 24 \\
\hline & DxN-3570 & 5.7 & 14 & 5 & 2.7 & 7 \\
\hline & NxM-3729 & 14.1 & 92 & 36 & 13.8 & 50 \\
\hline SE & & 1.3 & 40 & 13 & 3.4 & 16 \\
\hline$p$ & & $<0.001$ & $<0.001$ & $<0.001$ & $<0.001$ & $<0.001$ \\
\hline
\end{tabular}


Table 6. Site $\times$ Clone interaction for survival and mean annual yield in 13 year-old poplar plantations. The branch biomass ratio is the percentage of woody aboveground biomass that is branch biomass. Woody biomass yield after 8 years is also indicated along with the yield variation between 8 and 13 year-old plantations. Key environmental variables (elevation and soil available P) are indicated for each site (see Truax et al. [11]).

\begin{tabular}{|c|c|c|c|c|c|c|c|c|c|}
\hline $\begin{array}{c}\text { Sites and Key } \\
\text { Environmental } \\
\text { Variables } \\
\end{array}$ & Clones & $\begin{array}{c}\text { Survival } \\
(\%)\end{array}$ & $\begin{array}{c}\text { Stem } \\
\text { Volume } \\
\left(\mathbf{m}^{3} / \mathbf{h a} / \mathbf{y r}\right) \\
\end{array}$ & $\begin{array}{c}\text { Stem } \\
\text { Biomass } \\
(\mathrm{t} / \mathbf{h a} / \mathbf{y r}) \\
\end{array}$ & $\begin{array}{l}\text { Branch } \\
\text { Biomass } \\
(\mathrm{t} / \mathbf{h a} / \mathbf{y r}) \\
\end{array}$ & $\begin{array}{c}\text { Branch } \\
\text { Biomass } \\
\text { Ratio (\%) } \\
\end{array}$ & \multicolumn{2}{|c|}{$\begin{array}{c}\text { Aboveground } \\
\text { Woody Biomass } \\
(\mathrm{t} / \mathrm{ha} / \mathbf{y r})\end{array}$} & $\begin{array}{c}\text { Variation } 8 \text { vs. } \\
13 \text { Years } \\
(\mathrm{t} / \mathrm{ha} / \mathbf{y r}) \\
\end{array}$ \\
\hline & & \multicolumn{5}{|c|}{13 Years } & 8 Years & 13 Years & \\
\hline Bedford & MxB-915311 & 89 & 20.3 & 6.9 & 2.1 & 23 & 8.0 & 9.0 & +1.0 \\
\hline $80 \mathrm{~m}$ & DNxM-915508 & 89 & 31.4 & 10.8 & 3.5 & 25 & 12.3 & 14.3 & +2.0 \\
\hline \multirow[t]{3}{*}{$77 \mathrm{~kg}$ P/ha } & TxD-3230 & 83 & 28.4 & 9.1 & 1.6 & 15 & 8.7 & 10.7 & +2.0 \\
\hline & DxN-3570 & 81 & 30.9 & 9.6 & 1.7 & 15 & 7.6 & 11.2 & +3.6 \\
\hline & NxM-3729 & 75 & 26.1 & 9.0 & 2.8 & 23 & 12.6 & 11.8 & -0.8 \\
\hline Brompton & MxB-915311 & 92 & 20.2 & 6.9 & 2.1 & 23 & 6.8 & 9.0 & +2.1 \\
\hline $170 \mathrm{~m}$ & DNxM-915508 & 83 & 19.6 & 6.8 & 2.3 & 25 & 6.3 & 9.1 & +2.8 \\
\hline \multirow[t]{3}{*}{$60 \mathrm{~kg} \mathrm{P} / \mathrm{ha}$} & TxD-3230 & 92 & 27.4 & 8.8 & 1.6 & 16 & 7.0 & 10.5 & +3.5 \\
\hline & DxN-3570 & 89 & 19.5 & 6.1 & 1.1 & 15 & 5.9 & 7.2 & +1.3 \\
\hline & NxM-3729 & 92 & 26.5 & 9.3 & 2.8 & 23 & 9.6 & 12.1 & +2.4 \\
\hline Ste-Catherine & MxB-915311 & 92 & 11.9 & 4.1 & 1.3 & 24 & 3.3 & 5.4 & +2.1 \\
\hline $230 \mathrm{~m}$ & DNxM-915508 & 89 & 15.5 & 5.5 & 1.8 & 25 & 4.7 & 7.3 & +2.7 \\
\hline \multirow[t]{3}{*}{$50 \mathrm{~kg} \mathrm{P} / \mathrm{ha}$} & TxD-3230 & 89 & 16.1 & 5.3 & 1.1 & 17 & 4.3 & 6.4 & +2.1 \\
\hline & DxN-3570 & 89 & 9.0 & 2.9 & 0.5 & 15 & 2.8 & 3.4 & +0.6 \\
\hline & NxM-3729 & 92 & 17.1 & 6.1 & 1.9 & 23 & 6.0 & 8.0 & +2.0 \\
\hline La Patrie & MxB-915311 & 83 & 16.5 & 5.7 & 1.7 & 23 & 5.7 & 7.3 & +1.6 \\
\hline $440 \mathrm{~m}$ & DNxM-915508 & 92 & 14.8 & 5.3 & 1.8 & 25 & 5.0 & 7.0 & +2.0 \\
\hline \multirow[t]{3}{*}{$58 \mathrm{~kg} \mathrm{P} / \mathrm{ha}$} & TxD-3230 & 42 & 11.0 & 3.6 & 0.7 & 16 & 3.4 & 4.2 & +0.9 \\
\hline & DxN-3570 & 33 & 2.1 & 0.7 & 0.1 & 16 & 0.8 & 0.8 & 0 \\
\hline & NxM-3729 & 92 & 22.3 & 7.9 & 2.4 & 23 & 8.2 & 10.3 & +2.1 \\
\hline Melbourne & MxB-915311 & 89 & 18.3 & 6.3 & 1.9 & 23 & 4.1 & 8.2 & +4.1 \\
\hline $330 \mathrm{~m}$ & DNxM-915508 & 75 & 13.8 & 4.9 & 1.6 & 25 & 3.1 & 6.5 & +3.4 \\
\hline \multirow[t]{3}{*}{$17 \mathrm{~kg} \mathrm{P} / \mathrm{ha}$} & TxD-3230 & 31 & 6.0 & 2.0 & 0.4 & 17 & 1.4 & 2.4 & +1.0 \\
\hline & DxN-3570 & 50 & 4.4 & 1.4 & 0.3 & 16 & 1.1 & 1.7 & +0.6 \\
\hline & NxM-3729 & 92 & 15.5 & 5.6 & 1.7 & 23 & 5.3 & 7.3 & +2.0 \\
\hline Fitch Bay & MxB-915311 & 72 & 9.7 & 3.4 & 1.1 & 24 & 2.0 & 4.4 & +2.4 \\
\hline $260 \mathrm{~m}$ & DNxM-915508 & 53 & 9.8 & 3.4 & 1.1 & 25 & 2.0 & 4.6 & +2.6 \\
\hline \multirow[t]{3}{*}{$12 \mathrm{~kg} \mathrm{P} / \mathrm{ha}$} & TxD-3230 & 25 & 5.8 & 1.9 & 0.4 & 17 & 1.2 & 2.3 & +1.0 \\
\hline & DxN-3570 & 8 & 0.2 & 0.1 & 0.0 & 22 & 0.1 & 0.1 & 0 \\
\hline & NxM-3729 & 69 & 11.3 & 4.1 & 1.3 & 23 & 3.1 & 5.4 & +2.3 \\
\hline Ham & MxB-915311 & 92 & 7.5 & 2.6 & 0.9 & 26 & 2.1 & 3.6 & +1.5 \\
\hline $320 \mathrm{~m}$ & DNxM-915508 & 89 & 6.9 & 2.5 & 0.9 & 26 & 2.0 & 3.4 & +1.5 \\
\hline \multirow[t]{3}{*}{$26 \mathrm{~kg} \mathrm{P} / \mathrm{ha}$} & TxD-3230 & 81 & 7.6 & 2.6 & 0.7 & 20 & 2.5 & 3.2 & +0.7 \\
\hline & DxN-3570 & 64 & 1.6 & 0.5 & 0.1 & 20 & 0.6 & 0.7 & +0.1 \\
\hline & NxM-3729 & 92 & 6.6 & 2.6 & 0.9 & 26 & 2.7 & 3.5 & +0.8 \\
\hline
\end{tabular}


Table 6. Cont.

\begin{tabular}{|c|c|c|c|c|c|c|c|c|c|}
\hline \multirow[t]{2}{*}{$\begin{array}{c}\text { Sites and Key } \\
\text { Environmental } \\
\text { Variables } \\
\end{array}$} & \multirow[t]{2}{*}{ Clones } & $\begin{array}{c}\text { Survival } \\
(\%)\end{array}$ & $\begin{array}{c}\text { Stem } \\
\text { Volume } \\
\left(\mathbf{m}^{3} / \mathbf{h a} / \mathbf{y r}\right) \\
\end{array}$ & $\begin{array}{c}\text { Stem } \\
\text { Biomass } \\
(\mathbf{t} / \mathbf{h a} / \mathbf{y r}) \\
\end{array}$ & $\begin{array}{c}\text { Branch } \\
\text { Biomass } \\
(\mathrm{t} / \mathrm{ha} / \mathbf{y r}) \\
\end{array}$ & $\begin{array}{c}\text { Branch } \\
\text { Biomass } \\
\text { Ratio (\%) } \\
\end{array}$ & \multicolumn{2}{|c|}{$\begin{array}{c}\text { Aboveground } \\
\text { Woody Biomass } \\
(\mathrm{t} / \mathrm{ha} / \mathbf{y r})\end{array}$} & \multirow[t]{2}{*}{$\begin{array}{c}\text { Variation } 8 v s . \\
13 \text { years } \\
(t / h a / y r) \\
\end{array}$} \\
\hline & & \multicolumn{5}{|c|}{13 Years } & 8 Years & 13 Years & \\
\hline Stornoway & MxB-915311 & 92 & 4.9 & 1.7 & 0.7 & 29 & 1.1 & 2.5 & +1.3 \\
\hline $450 \mathrm{~m}$ & DNxM-915508 & 78 & 2.6 & 1.0 & 0.4 & 27 & 0.8 & 1.3 & +0.5 \\
\hline \multirow[t]{3}{*}{$9 \mathrm{~kg} \mathrm{P} / \mathrm{ha}$} & TxD-3230 & 39 & 1.1 & 0.4 & 0.1 & 27 & 0.3 & 0.5 & +0.2 \\
\hline & DxN-3570 & 17 & 0.3 & 0.1 & 0.0 & 27 & 0.1 & 0.1 & 0 \\
\hline & NxM-3729 & 86 & 5.1 & 2.0 & 0.8 & 28 & 1.6 & 2.8 & +1.2 \\
\hline SE & & 7 & 1.9 & 0.6 & 0.2 & - & 0.6 & 0.8 & - \\
\hline$p$ & & $<0.001$ & $<0.001$ & $<0.001$ & $<0.001$ & - & $<0.001$ & $<0.001$ & - \\
\hline
\end{tabular}

High yields were also observed at the Brompton site, which had similar soil chemical characteristics (Table 1), but slightly higher elevation $(170 \mathrm{~m})$ than the Bedford site. At this site, mean DBH reached $22.8-27.7 \mathrm{~cm}$, while mean tree volume and mean annual yield reached $342-467 \mathrm{dm}^{3} /$ tree and 19.5-27.4 $\mathrm{m}^{3} / \mathrm{ha} /$ year or 7.2-12.1 t/ha/year, depending on the clone (Tables 5 and 6). The yields observed at the Bedford and Brompton sites after 13 years were also comparable to the most productive plantations of Sweden and Denmark [24,26], which were grown under similar climatic conditions and silvicultural regime.

The two high soil fertility sites (Bedford and Brompton) also experienced the greatest increases in volume and biomass growth from year 8 to year 13. During this 5 year period, a net gain of 178 and $170 \mathrm{~m}^{3} /$ ha, or 69.5 and $67.3 \mathrm{t} / \mathrm{ha}$, was observed at the Bedford and Brompton sites respectively (Table 7). Consequently, the productivity gap between the high yielding and the low yielding sites (Fitch Bay, Ham and Stornoway) has widened from year 8 to year 13. For example, after 8 years, Bedford and Stornoway had cumulated 179 and $8 \mathrm{~m}^{3} /$ ha respectively, for a productivity gap of $171 \mathrm{~m}^{3} /$ ha between these two sites. After 13 years, the same two sites had cumulated 357 and $36 \mathrm{~m}^{3} / \mathrm{ha}$ respectively, for a productivity gap of $321 \mathrm{~m}^{3} /$ ha. From year 8 to year 13 , the productivity gap has also widened between sites with moderate yields (Ste-Catherine, La Patrie and Melbourne) and sites with high yields (Bedford and Brompton).

Our results also suggest that some poplar genotypes are generalists, while others appeared to be specialists, a trend that was equally observed in other studies [13,24]. In other words, clone selection is very important to optimize wood or biomass production along environmental gradients. Clones having a P. maximoviczii parentage (MxB-915311, DNxM-915508, NxM-3729) were generalists, because they had the smallest yield variation across the studied gradient, a trend equally observed in Denmark [24]. In addition, when yield at the end of the 8th and 13th growing season were compared, P. maximoviczii hybrids had the greatest yield increase on higher elevation and/or poorer sites (Ste-Catherine, La Patrie, Melbourne, Fitch Bay, Ham and Stornoway) (Tables 1 and 6). On the other hand, Euramerican hybrids (clones TxD-3230 and DxN-3570) were specialists, being only productive on low elevation fertile sites (Bedford and Brompton). In addition, at the Bedford site, the yield of clone DxN-3570 showed the greatest increase $(+3.6 \mathrm{t} / \mathrm{ha} /$ year) when 8 and 13 years yield data were compared. Consequently, at this site, clone DxN-3570 was the least productive at year 8 , but was among the most productive ones at year 13 (Table 6). This suggests that important productivity gains can be obtained by managing clone 
DxN-3570 on longer rotations on bottomland sites. However, a longer rotation (13 vs. 8 years) only leads to marginal or nil yield gains for this clone on the other sites (Table 6). The same could be said about clone TxD-3230, which experienced the second greatest productivity gain at Bedford $(+2.0 \mathrm{t} / \mathrm{ha} /$ year) and the greatest productivity gain at Brompton, $(+3.5 \mathrm{t} / \mathrm{ha} /$ year) (Table 6$)$, the other low elevation fertile site (Table 1). However, on higher elevation sites gains for the TxD-3230 clone were marginal.

Table 7. Site effect for total stem volume and woody biomass production and mean annual volume and biomass yield for 8 and 13 year-old poplar plantations. The volume and biomass increases from year 8 to 13 is indicated. Data for 8 year-old plantations were taken from Truax et al. [11].

\begin{tabular}{|c|c|c|c|c|c|c|c|c|c|c|}
\hline \multirow[t]{2}{*}{ Sites } & \multicolumn{2}{|c|}{$\begin{array}{c}\text { Total Volume } \\
\left(\mathbf{m}^{3} / \mathbf{h a}\right) \\
\end{array}$} & \multirow[t]{2}{*}{$\begin{array}{c}\text { Increase } \\
\left(\mathbf{m}^{3} / \mathbf{h a}\right) \\
\end{array}$} & \multicolumn{2}{|c|}{$\begin{array}{c}\text { Volume Yield } \\
\left(\mathbf{m}^{3} / \mathbf{h a} / \mathbf{y r}\right)\end{array}$} & \multicolumn{2}{|c|}{$\begin{array}{c}\text { Total Woody } \\
\text { Biomass (t/ha) }\end{array}$} & \multirow[t]{2}{*}{$\begin{array}{c}\text { Increase } \\
\text { (t/ha) }\end{array}$} & \multicolumn{2}{|c|}{$\begin{array}{c}\text { Woody Biomass } \\
\text { Yield (t/ha/yr) }\end{array}$} \\
\hline & 8 Years & 13 Years & & 8 Years & 13 Years & 8 Years & 13 Years & & 8 Years & 13 Years \\
\hline Bedford & 179 & 357 & 178 & 22.4 & 27.5 & 78.7 & 148 & 69.5 & 9.8 & 11.4 \\
\hline Brompton & 125 & 295 & 170 & 15.7 & 22.7 & 57.1 & 124 & 67.3 & 7.1 & 9.6 \\
\hline Ste-Catherine & 68 & 181 & 113 & 8.5 & 13.9 & 33.7 & 79 & 45.8 & 4.2 & 6.1 \\
\hline La Patrie & 75 & 174 & 99 & 9.4 & 13.4 & 36.9 & 77 & 40.3 & 4.6 & 5.9 \\
\hline Melbourne & 46 & 151 & 105 & 5.8 & 11.6 & 23.9 & 68 & 43.8 & 3.0 & 5.2 \\
\hline Fitch Bay & 24 & 96 & 72 & 3.1 & 7.4 & 13.4 & 44 & 30.1 & 1.7 & 3.3 \\
\hline Ham & 27 & 79 & 51 & 3.4 & 6.1 & 15.7 & 37 & 21.6 & 2.0 & 2.9 \\
\hline Stornoway & 8 & 36 & 28 & 1.1 & 2.8 & 6.4 & 19 & 12.4 & 0.8 & 1.4 \\
\hline SE & 5 & 11 & - & 0.6 & 0.9 & 2.1 & 5 & - & 0.3 & 0.4 \\
\hline$p$ & $<0.001$ & $<0.001$ & - & $<0.001$ & $<0.001$ & $<0.001$ & $<0.001$ & - & $<0.001$ & $<0.001$ \\
\hline
\end{tabular}

These trends may be related to the greater cold hardiness of $P$. maximoviczii hybrids compared to $P$. deltoides hybrids. In their natural habitats, poplars from the Tacamahaca section such as $P$. maximoviczii and $P$. balsamifera, are widely distributed in the northern latitudes, growing to the latitudinal limits of trees [54]. Conversely, poplars from the Aigeiros section, such as $P$. deltoides, are better adapted to the riparian habitats of the bottomlands of temperate and arid regions [54,55]. This could explain the lower survival and yields of clones DxN-3570 and TxD-3230, compared to the P. maximoviczii hybrids, on high elevation sites such as Stornoway, Melbourne and La Patrie (Table 6). Despite this lower survival, clone TxD-3230 has produced relatively large trees on these sites (Table 5). However, many of these large trees were heavily damaged by sunscalds (B. Truax and J. Fortier, field observations), reflecting the vulnerability of this clone to cold damages. Clones DxN-3570 and TxD-3230 were also more heavily browsed by deer following planting, which may have reduced their survival and early growth [11]. Consequently, when planted in more stressful environments, in terms of climate, soil fertility and herbivore pressure, these two clones were less productive than $P$. maximoviczii hybrids.

From a physiological perspective, the very low productivity of clone DxN-3570 on higher elevation sites suggests that it may be poorly adapted to soil conditions prevailing in colder sites (lower $\mathrm{N}$ mineralization rate). In a previous field experiment involving the same poplar genotypes, clone DxN-3570 had the greatest leaf nitrate reductase activity (NRA), and was the only clone that showed an increase in NRA in response to a soil increase in nitrate $\left(\mathrm{NO}_{3}\right)$ availability [56]. This evidence suggested that 
this clone has a greater ability for $\mathrm{NO}_{3}$ assimilation in its leaves than the other clones, potentially reflecting its preference for soil $\mathrm{NO}_{3}$ over $\mathrm{NH}_{4}$, as also observed for $P$. deltoides [18,57]. In temperate bottomland habitats, soil $\mathrm{NO}_{3}$ is generally the dominant $\mathrm{N}$-form in soils with a good drainage [58,59]. This could explain why clone DxN-3570 was among the most productive clones at the Bedford site, the only rich bottomland site in this study. On all the other sites, clone DxN-3570 was the least productive clone (Tables 5 and 6), reflecting its specialization for warm and rich bottomland sites.

Although clone MxB-915311 was a generalist clone in this study, it may not be the best choice in rich bottomland sites since its yield at the Bedford site $\left(20.5 \mathrm{~m}^{3} / \mathrm{ha} / \mathrm{yr}\right)$ was much lower than that of the other clones (26.1-31.4 m³/ha/yr). Having both of its parental species belonging to the Tacamahaca (balsam poplar) section, clone MxB-915311 may be more adapted to colder and wetter sites where the dominant soil $\mathrm{N}$-form is often $\mathrm{NH}_{4}$. Its parental species $P$. balsamifera was also found to prefer soil $\mathrm{NH}_{4}$ over $\mathrm{NO}_{3}$ [15], but also to have the ability to short-circuit the mineralization step of decomposition by absorbing directly amino-acids in environments with low $N$-mineralization rates and low inorganic $\mathrm{N}$ stocks (cold climates and wet soils) [60,61].

In addition to potential differences in cold hardiness and soil $\mathrm{N}$-form preferences of the studied genotypes, other factors could explain why some clones performed better than others on lower fertility sites. Several endophytic bacteria from poplars can promote the growth of their host plant by providing $\mathrm{N}$-fixation, growth regulators or by preventing the growth or activity of plant pathogens $[62,63]$. Poplar growth can also be promoted by the colonization of fungal endophytes, but also ectomycorrhizal and arbuscular mycorrhizal fungi [64]. The effects of those symbiotic associations have been found to be strongly influenced by poplar genotypes, as well as environmental conditions $[64,65]$. Consequently, across the environmental gradients studied, some genotypes may have benefited from those symbiotic associations more than others.

After eight years, clone NxM-3729 had the greatest productivity and survival rate on all sites across the climate and site fertility gradient studied [11]. Five years later, this clone was still among the most productive ones at most sites (Tables 5 and 6). However, at the fertile site of Bedford, clone NxM-3729 fell in 2nd position for biomass yield and in 4th position for volume yield. At this site, several trees of this clone showed symptoms of Septoria musiva (stem canker) infection (B. Truax and J. Fortier, field observations), which may have increased tree mortality and lowered its growth rate. At Bedford, clone NxM-3729 was the only clone to have a lower biomass yield at 13 years than at 8 years (Table 6). This situation highlights the need for planting a diversity of clones, in mono-specific blocks, in order to increase plantation resilience, while avoiding interspecific competition [66,67].

\subsection{Clone-Specific or General Equations for Estimating Poplar Plantation Yield?}

In Table 8, we compare volume and biomass yield calculations after 13 years using clone-specific and general allometric relationships developed with 13 year-old poplars (see Table 3). This comparison is presented for each clone, but also at the site level, at three representative sites along the studied environmental gradients. Although both approaches lead to similar estimates at the site level (5 clone mean), important variations in estimated yields were observed for the different clones at the site level. The use of the general allometric relationships resulted in an overestimation of yield for Euramerican hybrids (clones DxN-3570 and TxD-3230) and an underestimation of yield for P. maximoviczii hybrids 
(clones MxB-915311, DNxM-915508 and NxM-3729), which is a direct consequence of the different tree allometries between those two clone groups (Figure 1). With our data set, the general equation would lead to volume and woody biomass yield overestimations of up to $14.8 \%$ and $21.5 \%$ respectively, for Euramerican hybrids, and underestimations of up to $8.9 \%$ and $14.4 \%$ respectively, for $P$. maximoviczii hybrids (Table 8). The largest variations in estimates were associated with the use of the general equation for the calculation of branch biomass, with an overestimation reaching $68.4 \%$ for the branch biomass yield of clone TxD-3230 at Ste-Catherine. Consequently, there is a clear gain in accuracy, at the clone level, with the use of clone-specific volume or biomass equations for yield calculations, and ultimately for nutrient and carbon stocks calculations in the different biomass compartments.

Table 8. Yield data after 13 years for each clone across three representative sites, calculated using both clone-specific and general allometric relationships developed with 13 year-old trees. Site means are also indicated ( 5 clone mean) along with the percent difference $(\Delta \%)$ associated to the use of general equations over clone-specific ones.

\begin{tabular}{|c|c|c|c|c|c|c|c|c|c|c|c|c|}
\hline \multirow[t]{2}{*}{$\begin{array}{c}\text { Sites and } \\
\text { Clones }\end{array}$} & \multicolumn{2}{|c|}{$\begin{array}{c}\text { Volume Yield } \\
\left(\mathrm{m}^{3} / \mathrm{ha} / \mathbf{y r}\right) \\
\end{array}$} & \multirow[t]{2}{*}{$\begin{array}{c}\Delta \\
(\%)\end{array}$} & \multicolumn{2}{|c|}{$\begin{array}{l}\text { Stem Biomass } \\
\text { Yield (t/ha/yr) }\end{array}$} & \multirow[t]{2}{*}{$\begin{array}{c}\Delta \\
(\%)\end{array}$} & \multicolumn{2}{|c|}{$\begin{array}{c}\text { Branch Biomass } \\
\text { Yield (t/ha/yr) }\end{array}$} & \multirow[t]{2}{*}{$\begin{array}{c}\Delta \\
(\%)\end{array}$} & \multicolumn{2}{|c|}{$\begin{array}{c}\text { Woody Biomass } \\
\text { Yield (t/ha/yr) }\end{array}$} & \multirow[t]{2}{*}{$\Delta(\%)$} \\
\hline & $\begin{array}{r}\text { Clone } \\
\text { Specific } \\
\end{array}$ & General & & \begin{tabular}{|c|} 
Clone \\
Specific \\
\end{tabular} & General & & $\begin{array}{c}\text { Clone } \\
\text { Specific } \\
\end{array}$ & General & & $\begin{array}{c}\text { Clone } \\
\text { Specific } \\
\end{array}$ & General & \\
\hline Bedford & & & & & & & & & & & & \\
\hline MxB-915311 & 20.5 & 18.7 & -8.9 & 6.9 & 6.4 & -8.0 & 2.07 & 1.67 & -19.2 & 9.0 & 8.0 & -10.6 \\
\hline DNxM-915508 & 31.4 & 29.0 & -7.7 & 10.8 & 9.8 & -9.0 & 3.52 & 2.43 & -30.9 & 14.3 & 12.2 & -14.4 \\
\hline TxD-3230 & 28.4 & 31.1 & +9.6 & 9.1 & 10.5 & +15.1 & 1.62 & 2.54 & +57.2 & 10.7 & 13.0 & +21.5 \\
\hline DxN-3570 & 30.9 & 32.7 & +6.0 & 9.6 & 11.0 & +14.6 & 1.65 & 2.63 & +59.1 & 11.2 & 13.6 & +21.1 \\
\hline NxM-3729 & 26.1 & 24.6 & -5.9 & 9.0 & 8.3 & -8.1 & 2.77 & 2.06 & -25.6 & 11.8 & 10.4 & -12.2 \\
\hline 5 clone mean & 27.5 & 27.2 & -0.9 & 9.1 & 9.2 & +1.1 & 2.33 & 2.27 & -2.5 & 11.4 & 11.4 & 0.4 \\
\hline \multicolumn{13}{|l|}{ Ste-Catherine } \\
\hline MxB-915311 & 12.0 & 11.0 & -7.9 & 4.1 & 3.8 & -7.5 & 1.30 & 1.07 & -17.4 & 5.4 & 4.9 & -9.9 \\
\hline DNxM-915508 & 15.5 & 14.7 & -4.9 & 5.5 & 5.1 & -7.8 & 1.85 & 1.36 & -26.3 & 7.3 & 6.4 & -12.5 \\
\hline TxD-3230 & 16.1 & 18.0 & +12.1 & 5.3 & 6.1 & +16.0 & 1.12 & 1.60 & +43.1 & 6.4 & 7.7 & +20.8 \\
\hline DxN-3570 & 9.0 & 9.2 & +2.6 & 2.9 & 3.2 & +11.1 & 0.52 & 0.88 & +68.4 & 3.4 & 4.1 & +19.9 \\
\hline NxM-3729 & 17.1 & 16.7 & -2.3 & 6.1 & 5.7 & -7.2 & 1.86 & 1.52 & -18.4 & 8.0 & 7.2 & -9.8 \\
\hline 5 clone mean & 13.9 & 13.9 & +0.1 & 4.8 & 4.8 & -0.1 & 1.33 & 1.29 & -3.2 & 6.1 & 6.1 & -0.7 \\
\hline \multicolumn{13}{|l|}{ Ham } \\
\hline MxB-915311 & 7.6 & 7.0 & -7.1 & 2.6 & 2.5 & -7.1 & 0.93 & 0.73 & -21.9 & 3.6 & 3.2 & -11.0 \\
\hline DNxM-915508 & 6.9 & 6.8 & -1.5 & 2.5 & 2.4 & -6.3 & 0.89 & 0.71 & -20.6 & 3.4 & 3.1 & -10.0 \\
\hline TxD-3230 & 7.6 & 8.7 & +14.8 & 2.6 & 3.0 & +17.1 & 0.66 & 0.85 & +29.1 & 3.2 & 3.8 & +19.5 \\
\hline DxN-3570 & 1.6 & 1.6 & -1.7 & 0.5 & 0.6 & +6.6 & 0.14 & 0.19 & +41.2 & 0.7 & 0.8 & +13.6 \\
\hline NxM-3729 & 6.6 & 6.9 & +4.1 & 2.6 & 2.4 & -5.6 & 0.92 & 0.72 & -21.4 & 3.5 & 3.1 & -9.8 \\
\hline 5 clone mean & 6.1 & 6.2 & 2.4 & 2.2 & 2.2 & -0.2 & 0.71 & 0.64 & -9.5 & 2.9 & 2.8 & -2.5 \\
\hline
\end{tabular}

The ability of a general volume or biomass equation to provide accurate estimates for a given genotype will also be highly dependent upon the representativeness of this genotype in the sample used to develop the general equation. In other words, increasing the proportion of observations related to $P$. maximoviczii hybrids in our general equation will likely lead to greater volume or biomass overestimations of Euramerican clones, and vice-versa. 


\subsection{Management Implications}

In temperate regions, short rotation woody crop yields should ideally fall within the range of $10-30 \mathrm{~m}^{3} / \mathrm{ha} / \mathrm{yr}$, depending on site quality, clones, local climate and cultivation methods [68]. Taking these numbers as a bench mark, our study suggests that 5 of our study sites out of 8 had produced a satisfactory wood volume after 13 years. On these 5 best sites, wood and biomass production ranged from $151 \mathrm{~m}^{3} /$ ha (or $68 \mathrm{t} / \mathrm{ha}$ ) at Melbourne up to $357 \mathrm{~m}^{3} / \mathrm{ha}$ (or $148 \mathrm{t} / \mathrm{ha}$ ) at Bedford (Table 7). Higher yields could have been obtained on all of these 5 sites by selecting the clones that were better adapted to site characteristics, as revealed by the significant Site $\times$ Clone interactions (Tables 5 and 6). Although some genotypes are generalists, being able to produce moderate to high yields on a variety of sites, clone selection is still very important to optimize yields across environmental gradients.

Despite the fact that the 3 low productivity sites (Fitch Bay, Ham, Stornoway) had increased their mean annual increments or yields from year 8 to year 13 (Table 7), they still have a marginal productivity after 13 years. While some genotypes were more productive than others on these low yielding sites, clone selection alone cannot compensate for poor site selection, as equally observed in South Carolina, United States [27]. In other words, not all abandoned farmland sites of southern Québec are suitable for poplar cultivation, which corroborates similar observations in France [69].

It could be argued that poplar plantations should be managed on longer rotations on these low productivity sites. However, hybrid poplars are short-lived trees because they are highly susceptible to diseases and pest outbreak [16]. In addition, hybrid poplars tend to have low mechanical strength properties [70], which make them susceptible to stem breakages during severe climatic events such as windstorms or ice storms. Since those climatic events are episodically observed in the southern Québec region, a low risk management approach for the production of pulpwood and sawlogs would be the use of high quality sites, with intermediate rotation length (12-15 years) for planting densities around $833 \mathrm{stem} / \mathrm{ha}$. At the beginning of the 15 th growing season, we observed severe damages (broken crowns, bent trees, uprooted trees) at the La Patrie plantation caused by climatic events, which suggests that long rotations (more than 15 years) might be risky for the studied region. Besides, time did not play in favor of the low yielding sites since the productivity gap between the more and less productive sites has widened over the years (Table 7). If biomass for bioenergy is also an objective, a planting density reaching up to $2500 \mathrm{stems} / \mathrm{ha}$ could be used, with half of the trees being thinned earlier in the rotation, allowing the remaining trees to reach pulpwood diameter for the final harvest, as recommended in Sweden [26].

The allometric relationships developed in this study, as well as the branch biomass ratio calculated for the different clones at each site (Figure 1 and Table 6), suggest important genotypic variation in patterns of biomass allocation to branches. Our observations showed that $P$. maximoviczii hybrids allocated a larger proportion of their woody biomass to branches compared to clones DxN-3570 and TxD-3230. This trait of $P$. maximoviczii hybrids may not be desirable when the objective is to produce higher quality products (veneer or sawlogs) since pruning trees with greater branch biomass will be more time-consuming or expensive. On the other hand, the greater branch biomass proportion of P. maximovizcii hybrids favors rapid canopy closure, which is important to restore key forest understory attributes such as shade and low herbaceous cover $[6,71,72]$. 
Finally, this study suggests that clone-specific and age-specific allometric relationships will provide more accurate estimates of wood volume and woody biomass. Increasing the accuracy of volume and biomass estimates of standing trees could be especially helpful in supporting management decisions regarding the timing of harvest or thinning operations.

\section{Conclusions}

This study provides evidence that allometry varies significantly for poplar clones of different parentages, which resulted in more accurate volume or biomass estimates by using clone-specific equations over general ones. Given that some clones had a similar allometry after 13 years of growth, more general allometric relationships could eventually be developed for different groups of clones or hybrids ( $P$. maximoviczii vs. Euramerican hybrids).

Yields measured after 13 years of growth suggest that low elevation abandoned farmland sites with high soil fertility are still the best suited for poplar culture in southern Québec. On the best site, located in the St. Lawrence Valley, a yield as high as $31.4 \mathrm{~m}^{3} / \mathrm{ha} / \mathrm{yr}$. was observed for the best clone. This study also shows that the productivity gap between the more and less productive sites has widened between year 8 and year 13, showing that increasing rotation length has produced a much greater gain on the high yielding sites. Finally, as suggested by the significant Site $\times$ Clone interactions on hybrid poplar yield, clone selection is very important to optimize yield across environmental gradients. In that perspective, high elevation but fertile sites are also promising if $P$. maximoviczii hybrids are selected. The Site $\times$ Clone interactions also suggested that Euramerican hybrids (DxN and TxD) were only productive on fertile sites located at low elevation. This contrasts with the generalist behavior of $P$. maximoviczii hybrids, which were able to produce moderate to high yields on a variety of sites across the studied gradient. Still, inadequate site selection in terms of soil fertility cannot be fully compensated by clone selection alone.

\section{Acknowledgments}

We gratefully acknowledge funding received from the Ministère des Ressources naturelles et de la Faune (MRNF) of Québec and Agriculture and Agri-food Canada (Agricultural Greenhouse Gas Program). We wish to thank Anne Déziel of the Berthierville MRNF nursery (which provided rooted cuttings), as well as Florent Lemieux and Carole Cormier of the MRNF regional office. Our gratitude goes to regional forestry advisors André Goulet, Nicolas Meagher, Pierre Bellavance, Ken Dubé, Alain Paris and Marc Beaubien, as well as Daniel Lambert, for assistance with site selection. Thanks also to all the owners of the plantation sites: Daniel Dubé, Carlo Iannuzzi, Harry Isbrucker, Pierre Pellerin, Jean Cloutier, Gilles Pellerin, Pierre Labrecque, Alfred Labbé, Mario Blais and Diane Benoît. We greatly appreciated the help of all our tree planters and field assistants (Robin Côté, Francis Mongeau, Jean-Sébastien Labrecque, Louis-Philippe Gagnon, Laurence Tétreault-Garneau, David Adam, Lionel Godbout, Joannie Lemelin, Denis Pageault, Annie Richard, Marc Blais). We would like to thank Serge Gendron, Réal Lamadeleine and Martin Poulin for giving us access to the wood drying facilities of Domtar Corp., Windsor, Quebec. A special thanks to Harry Isbrucker for providing us a large amount of space for sample storage and preparation. Thanks are also due to Robert Bradley and William Parsons, of the Centre d'étude de la forêt (CEF) laboratory at Université 
de Sherbrooke, for providing soil $\mathrm{C} / \mathrm{N}$ analyses. Finally, we gratefully acknowledge three anonymous reviewers for their positive and very constructive comments.

\section{Author Contributions}

The initial experimental design was structured and planted by Benoit Truax. The authors contributed equally to this work.

\section{Conflicts of Interest}

The authors declare no conflict of interest.

\section{References}

1. Ball, J.; Carle, J.; Lungo, A.D. Contribution of poplars and willows to sustainable forestry and rural development. Unasylva 2005, 56, 3-9.

2. Vance, E.; Loehle, C.; Wigley, T.; Weatherford, P. Scientific basis for sustainable management of Eucalyptus and Populus as short-rotation woody crops in the U.S. Forests 2014, 5, 901-918.

3. Archaux, F.; Martin, H. Hybrid poplar plantations in a floodplain have balanced impacts on farmland and woodland birds. For. Ecol. Manag. 2009, 257, 1474-1479.

4. Christian, D.P.; Hoffman, W.; Hanowski, J.M.; Niemi, G.J.; Beyea, J. Bird and mammal diversity on woody biomass plantations in North America. Biomass Bioenergy 1998, 14, 395-402.

5. Lust, N.; Kongs, T.; Nachtergale, L.; de Keersmaeker, L. Spontaneous ingrowth of tree species in poplar plantations in Flanders. Ann. For. Sci. 2001, 58, 861-868.

6. Boothroyd-Roberts, K.; Gagnon, D.; Truax, B. Can hybrid poplar plantations accelerate the restoration of forest understory attributes on abandoned fields? For. Ecol. Manag. 2013, 287, 77-89.

7. Fortier, J.; Gagnon, D.; Truax, B.; Lambert, F. Nutrient accumulation and carbon sequestration in 6 year-old hybrid poplars in multiclonal agricultural riparian buffer strips. Agric. Ecosyst. Environ. 2010, 137, 276-287.

8. Perry, C.H.; Miller, R.C.; Brooks, K.N. Impacts of short-rotation hybrid poplar plantations on regional water yield. For. Ecol. Manag. 2001, 143, 143-151.

9. Bergante, S.; Facciotto, G.; Minotta, G. Identification of the main site factors and management intensity affecting the establishment of Short-Rotation-Coppices (SRC) in Northern Italy through stepwise regression analysis. Cent. Eur. J. Biol. 2010, 5, 522-530.

10. Tabbush, P.; Beaton, A. Hybrid poplars: Present status and potential in Britain. Forestry 1998, 71, 355-364.

11. Truax, B.; Gagnon, D.; Fortier, J.; Lambert, F. Yield in 8 year-old hybrid poplar plantations on abandoned farmland along climatic and soil fertility gradients. For. Ecol. Manag. 2012, 267, 228-239.

12. Coleman, M.; Tolsted, D.; Nichols, T.; Johnson, W.D.; Wene, E.G.; Houghtaling, T. Post-establishment fertilization of Minnesota hybrid poplar plantations. Biomass Bioenergy 2006, 30, 740-749. 
13. Zalesny, R.; Hall, R.; Zalesny, J.; McMahon, B.; Berguson, W.; Stanosz, G. Biomass and genotype $\times$ environment interactions of Populus energy crops in the midwestern United States. BioEnergy Res. 2009, 2, 106-122.

14. Yu, Q.; Pulkkinen, P. Genotype-Environment interaction and stability in growth of aspen hybrid clones. For. Ecol. Manag. 2003, 173, 25-35.

15. Chapin, F.S.; Cleve, K.; Tryon, P.R. Relationship of ion absorption to growth rate in taiga trees. Oecologia 1986, 69, 238-242.

16. Dickmann, D.I. An overview of the genus Populus. In Poplar Culture in North America. Part A, Chapter 1; Dickmann, D.I., Isebrands, J.G., Eckenwalder, J.E., Richardson, J., Eds.; NRC Research Press, National Research Council of Canada: Ottawa, ON, Canada, 2001; pp. 1-42.

17. Schweitzer, J.; Madritch, M.; Bailey, J.; LeRoy, C.; Fischer, D.; Rehill, B.; Lindroth, R.; Hagerman, A.; Wooley, S.; Hart, S.; et al. From genes to ecosystems: The genetic basis of condensed tannins and their role in nutrient regulation in a Populus model system. Ecosystem 2008, 11, 1005-1020.

18. Woolfolk, W.T.M.; Friend, A.L. Growth response of cottonwood roots to varied $\mathrm{NH}_{4}: \mathrm{NO}_{3}$ ratios in enriched patches. Tree Physiol. 2003, 23, 427-432.

19. Paris, P.; Mareschi, L.; Sabatti, M.; Pisanelli, A.; Ecosse, A.; Nardin, F.; Scarascia-Mugnozza, G. Comparing hybrid Populus clones for SRF across northern Italy after two biennial rotations: Survival, growth and yield. Biomass Bioenergy 2011, 35, 1524-1532.

20. Dillen, S.Y.; Djomo, S.N.; Al Afas, N.; Vanbeveren, S.; Ceulemans, R. Biomass yield and energy balance of a short-rotation poplar coppice with multiple clones on degraded land during 16 years. Biomass Bioenergy 2013, 56, 157-165.

21. Fortier, J.; Gagnon, D.; Truax, B.; Lambert, F. Biomass and volume yield after 6 years in multiclonal hybrid poplar riparian buffer strips. Biomass Bioenergy 2010, 34, 1028-1040.

22. Karacic, A.; Verwijst, T.; Weih, M. Above-ground woody biomass production of short-rotation Populus plantations on agricultural land in Sweden. Scand. J. For. Res. 2003, 18, 427-437.

23. Anderson, W.C.; Krinard, R.M. The investment potential of cottonwood sawtimber plantations. In Proceedings of the Third Biennial Southern Sylvicultural Research Conference, Atlanta, Georgia, 7-8 November 1984; Shoulders, E., Ed.; USDA Forest Service: Knoxville, TN, USA 1984; pp. 190-197.

24. Nielsen, U.B.; Madsen, P.; Hansen, J.K.; Nord-Larsen, T.; Nielsen, A.T. Production potential of 36 poplar clones grown at medium length rotation in Denmark. Biomass Bioenergy 2014, 64, 99-109.

25. Johansson, T.; Karačić, A. Increment and biomass in hybrid poplar and some practical implications. Biomass Bioenergy 2011, 35, 1925-1934.

26. Christersson, L. Wood production potential in poplar plantations in Sweden. Biomass Bioenergy 2010, 34, 1289-1299.

27. Kaczmarek, D.J.; Coyle, D.R.; Coleman, M.D. Survival and growth of a range of Populus clones in central South Carolina USA through age ten: Do early assessments reflect longer-term survival and growth trends? Biomass Bioenergy 2013, 49, 260-272.

28. Joss, B.; Hall, R.; Sidders, D.; Keddy, T. Fuzzy-logic modeling of land suitability for hybrid poplar across the Prairie Provinces of Canada. Environ. Monit. Assess. 2008, 141, 79-96. 
29. Schroeder, W.; Silim, S.; Patterson Fradette, J.; de Grooijer, H. Detailed Site Analysis and Mapping of Agroforestry Potential in the Northern Agricultural Zone of Saskatchewan; Agriculture and Agri-Food Canada, Final Report to Saskatchewan Forestry Centre: Indian Head, Canada, 2003.

30. Wang, D.; LeBauer, D.; Dietze, M. Predicting yields of short-rotation hybrid poplar (Populus spp.) for the United States through model-data synthesis. Ecol. Appl. 2012, 23, 944-958.

31. Headlee, W.; Zalesny, R., Jr.; Donner, D.; Hall, R. Using a process-based model (3-PG) to predict and map hybrid poplar biomass productivity in Minnesota and Wisconsin, USA. BioEnergy Res. 2013, 6, 196-210.

32. Chojnacky, D.C.; Heath, L.S.; Jenkins, J.C. Updated generalized biomass equations for North American tree species. Forestry 2014, 87, 129-151.

33. Brown, S. Measuring carbon in forests: Current status and future challenges. Environ. Poll. 2002, 116, 363-372.

34. Fortier, J.; Truax, B.; Gagnon, D.; Lambert, F. Mature hybrid poplar riparian buffers along farm streams produce high yields in response to soil fertility assessed using three methods. Sustainability 2013, 5, 1893-1916.

35. Verwijst, T.; Telenius, B. Biomass estimation procedures in short rotation forestry. For. Ecol. Manag. 1999, 121, 137-146.

36. Zabek, L.M.; Prescott, C.E. Biomass equations and carbon content of aboveground leafless biomass of hybrid poplar in Coastal British Columbia. For. Ecol. Manag. 2006, 223, 291-302.

37. DiRocco, T.L.; Ramage, B.S.; Evans, S.G.; Potts, M.D. Accountable accounting: Carbon-based management on marginal lands. Forests 2014, 5, 847-861.

38. Fatemi, F.R.; Yanai, R.D.; Hamburg, S.P.; Vadeboncoeur, M.A.; Arthur, M.A.; Briggs, R.D.; Levine, C.R. Allometric equations for young northern hardwoods: The importance of age-specific equations for estimating aboveground biomass. Can. J. For. Res. 2011, 41, 881-891.

39. Cann, D.B.; Lajoie, P. Études des sols des Comtés de Stanstead, Richmond, Sherbrooke et Compton dans la Province de Québec; Ministère de l'Agriculture: Ottawa, ON, Canada, 1943; p. 58.

40. Cann, D.B.; Lajoie, P.; Stobbe, P.C. Études des Sols des Comtés de Shefford, Brome et Missisquoi dans la Province de Québec; Ministère de l'agriculture: Ottawa, ON, Canada, 1948; p. 80.

41. Robitaille, A.; Saucier, J.-P. Paysages Régionaux du Québec Méridional; Les publications du Québec: Ste-Foy, QC, Canada, 1998; p. 213.

42. Petersen, R.G. Design and Analysis of Experiments; Marcel-Dekker: New York, NY, USA, 1985; p. 429.

43. Gotelli, N.J.; Ellison, A.M. A Primer of Ecological Statistics; Sinauer Associated, Inc.: Sunderland, MA, USA, 2004; p. 510.

44. Steel, R.G.D.; Torrie, J.H. Principles and Procedures of Statistics; McGraw-Hill: New York, NY, USA, 1980; p. 633.

45. Périnet, P.; Gagnon, H.; Morin, S. Liste des Clones Recommandés de Peuplier Hybride par Sous-Région Écologique au Québec (mise à jour octobre 2010); Direction de la recherche forestière, MRN: Québec, QC, Canada, 2010; p. 1.

46. West, P. Tree and Forest Measurement; Springer-Verglag: Berlin/Heidelberg, Germany, 2009; p. 190. 
47. Perron, J.-Y. Inventaire forestier. In Manuel de Foresterie; Ordre des ingénieurs forestiers du Québec, Ed.; Les Presses de l'Université Laval: Ste-Foy, QC, Canada, 1996; pp. 390-473.

48. Royston, P. An extension of Shapiro and Wilk's W test for normality to large samples. Appl. Stat. 1982, 31, 115-124.

49. Chambers, J.M.; Cleveland, W.S.; Kleiner, B.; Tukey, P.A. Graphical Methods for Data Analysis; Wadsworth International Group: Belmont, CA, USA, 1983.

50. Tuskan, G.A.; Rensema, T.R. Clonal differences in biomass characteristics, coppice ability, and biomass prediction equations among four Populus clones grown in eastern North Dakota. Can. J. For. Res. 1992, 22, 348-354.

51. DeBell, D.S.; Singleton, R.; Harrington, C.A.; Gartner, B.L. Wood density and fiber length in young Populus stems: Relation to clone, age, growth rate, and pruning. Wood Fiber Sci. 2002, 34, 529-539.

52. Fortier, J.; Truax, B.; Gagnon, D.; Lambert, F. Hybrid poplar yields in Québec: Implications for a sustainable forest zoning management system. For. Chron. 2012, 88, 391-407.

53. Labrecque, M.; Teodorescu, T.I. Field performance and biomass production of 12 willow and poplar clones in short-rotation coppice in southern Quebec (Canada). Biomass Bioenergy 2005, 29, 1-9.

54. Dickmann, D.I.; Kuzovkina, Y.A. Poplars and Willows of the World, with Emphasis on Silviculturally Important Species; Working Paper IPC/9-2FAO; Forest Management Division: Rome, Italy, 2008; p. 129.

55. Farrar, J.L. Les arbres du Canada; Fides et le Service canadien des forêts, Ressources naturelles Canada: St-Laurent, QC, Canada, 2006; p. 502.

56. Fortier, J.; Truax, B.; Lambert, F.; Gagnon, D.; Chevrier, N. Clone-specific response in leaf nitrate reductase activity among unrelated hybrid poplars in relation to soil nitrate availability. Int. J. For. Res. 2012, 2012, 1-10.

57. Woolfolk, W.T.M. Influence of Ammonium:Nitrate Ratio on Growth and N Accumulation of Populus deltoides. Master's Thesis, Mississippi State University, Starkville, MS, USA, 2000.

58. Rennenberg, H.; Wildhagen, H.; Ehlting, B. Nitrogen nutrition of poplar trees. Plant Biol. 2010, 12, 275-291.

59. Hefting, M.; Clément, J.C.; Dowrick, D.; Cosandey, A.C.; Bernal, S.; Cimpian, C.; Tatur, A.; Burt, T.P.; Pinay, G. Water table elevation controls on soil nitrogen cycling in riparian wetlands along a European climatic gradient. Biogeochemistry 2004, 67, 113-134.

60. Kielland, K. Amino acid absorption by arctic plants: Implications for plant nutrition and nitrogen cycling. Ecology 1994, 75, 2373-2383.

61. Kielland, K.; McFarland, J.; Olson, K. Amino acid uptake in deciduous and coniferous taiga ecosystems. Plant Soil 2006, 288, 297-307.

62. Van der Lelie, D.; Taghavi, S.; Monchy, S.; Schwender, J.; Miller, L.; Ferrieri, R.; Rogers, A.; $\mathrm{Wu}, \mathrm{X}$; Zhu, W.; Weyens, N.; et al. Poplar and its Bacterial Endophytes: Coexistence and Harmony. Crit. Rev. Plant Sci. 2009, 28, 346-358.

63. Doty, S.L.; Dosher, M.R.; Singleton, G.L.; Moore, A.L.; Aken, B.V.; Stettler, R.F.; Strand, S.E.; Gordon, M.P. Identification of an endophytic Rhizobium in stems of Populus. Symbiosis 2005, 39, 27-35. 
64. Karliński, L.; Rudawska, M.; Kieliszewska-Rokicka, B.; Leski, T. Relationship between genotype and soil environment during colonization of poplar roots by mycorrhizal and endophytic fungi. Mycorrhiza 2010, 20, 315-324.

65. Khasa, P.D.; Chakravarty, P.; Robertson, A.; Thomas, B.R.; Dancik, B.P. The mycorrhizal status of selected poplar clones introduced in Alberta. Biomass Bioenergy 2002, 22, 99-104.

66. Berthelot, A. Mélange de clones en taillis à courtes rotations de peuplier: Influence sur la productivité et l'homogénéité des produits récoltés. Can. J. For. Res. 2001, 31, 1116-1126.

67. Stanturf, J.A.; van Oosten, C.; Coleman, M.D.; Portwood, C.J. Ecology and silviculture of poplar plantations. In Poplar Culture in North America; Dickmann, D.I., Isebrands, J.G., Eckenwalder, J.E., Richardson, J., Eds.; NRC Research Press, National Research Council of Canada: Ottawa, ON, Canada, 2001; pp. 153-206.

68. Dickmann, D.I. Silviculture and biology of short-rotation woody crops in temperate regions: Then and now. Biomass Bioenergy 2006, 30, 696-705.

69. Soulères, G. Réflexions sur les perspectives actuelles de la populiculture en France. Rev. For. Fr. 1995, XLVII, 661-674.

70. Balatinecz, J.J.; Kretschmann, D.E.; Leclercq, A. Achievements in the utilization of poplar wood-guideposts for the future. For. Chron. 2001, 77, 265-269.

71. Boothroyd-Roberts, K.; Gagnon, D.; Truax, B. Hybrid poplar plantations are suitable habitat for reintroduced forest herbs with conservation status. Springer Plus 2013, 2, 1-13.

72. Fortier, J.; Gagnon, D.; Truax, B.; Lambert, F. Understory plant diversity and biomass in hybrid poplar riparian buffer strips in pastures. New For. 2011, 42, 241-265.

(C) 2014 by the authors; licensee MDPI, Basel, Switzerland. This article is an open access article distributed under the terms and conditions of the Creative Commons Attribution license (http://creativecommons.org/licenses/by/4.0/). 